plutonium in UK nuclear weapons originated in civil reactors.

The MOD reports do not separate the transfer data into weapons-grade and nonweapons-grade plutonium, and there are no data on production in the country's dedicated military reactors at Calder Hall and Chapel Cross.

We call on the MOD to provide this information. Similar data have been made public in the United States ${ }^{3}$. The UK government is now in an anomalous position, having published the military stockpile while refusing to publish similar figures for civil plutonium. We request that they do so, and clarify the contradictory statements that have been made to Parliament about the fate of civil plutonium.

The Magnox reactors have entered their shutdown phase and are again producing significant amounts of weapons-grade plutonium. The UK government has recently decided to restrict information on plutonium production in civil reactors ${ }^{7}$. One hopes that history will not repeat itself.

K. W. J. Barnham ${ }^{\star}$, J. Nelson*,

R. A. Stevens $\dagger$

${ }^{*}$ Physics Department, Imperial College of Science, Technology and Medicine, London SW7 2BW, UK $\dagger$ Join Systems, Menlo Park, California 94025, USA

1. Plutonium and Aldermaston: An Historical Account (Ministry of Defence, London, 2000). http://www.fas.org/news/uk/000414-uk2.htm

2. Historical Accounting and Plutonium (Ministry of Defence, London, 2000). http://www.fas.org/news/uk/ 000414-uk3.htm

3arnham, K. W. J., Hart, D., Nelson, J. \& Stevens, R. A. Nature 317, 213-217 (1985)

4. Layfield, F. Sizewell B Public Inquiry: Summary of Conclusions and Recommendations (Department of Energy, London, 1987).

Hansard 27-7-83, cols 439-440 (1983)

6. Plutonium: The First 50 Years (Department of Energy, Washington DC, 1996)

7. Barnham, K. W. J., Nelson, J. \& Stevens, R. A. Nature 395, 739 (1998).

\section{Achievers should stay to aid Brazilian science ...}

Sir - The Opinion article "Genome sequencing for all” (Nature 406, 109; 2000) exposed a patronising view of research in developing countries.

In my view, Nature could have used its valuable space to tackle more interesting, painful yet real issues surrounding scientists in developing countries (see the News feature "A springboard to success" in Nature 407, 440-441; 2000). For example, why was the Brazilian paper celebrated in your Opinion article an exception rather than the rule?

Local antinationalism has allowed imperialism from industrialized countries to survive for centuries. So, although I understand the views of the Brazilian scientists abroad "who frequently decide not to return, citing a lack of scientific opportunity", they are also being used as cheap labour in rich countries. Hence they are perpetuating an unfair situation by their short-sightedness and selfishness (very often their studies have been funded by Brazilian public money).

By leaving Brazil they may well avoid having to carry out less 'important' or 'glamorous' science. But they also lose the chance to involve themselves in relevant issues such as the dismantling of Brazil's public university system, or to claim the right to better jobs and working conditions, or to build a better future for themselves and for future generations. Maria J. Hötzel

Universidade Federal de Santa Catarina, CCADepartamento de Zootecnia e Desenvolvimento Rural, Rodovia Admar Gonzaga, 1346 Itacorubi 88.034.001, Florianópolis, Santa Catarina, Brazil

\section{... .yet the path is strewn with needless obstacles}

Sir - I am a young Brazilian scientist and I agree with Tomas Prolla's point in Correspondence ${ }^{1}$ that the rigid bureaucracy in Brazil turns scientific research into a nightmare.

Four years ago, I asked the director of the institute where I did my $\mathrm{PhD}$ to release funds (about US\$20) so I could send reprints to England, as one of my results was going to be cited in a textbook to be published there. The director punched his desk and said that he was not there to support my megalomania. I sent the reprints using my own money, and my result was cited in the book ${ }^{2}$. A professor from another university told me that to behave as I had done, at my level of seniority, would cause fear among my superiors.

I recently entered the selection process for a professor's position in one of Brazil's leading universities. One of the interviewers asked why I wanted to stay in academia instead of working in industry for better pay. I did not get the job.

The person who got the job has published about six papers in journals, and is corresponding author on none of these. My curriculum vitae lists 21 papers in good international journals. In 20 of these I am the corresponding author and in $11 \mathrm{I}$ am the sole author. I have spent $\$ 23,000$ of my own money doing serious research in this country and I receive about $\$ 200,000$ as a government grant. In my laboratory I have the first atomic force microscope for biological research in the country.

This is the fourteenth selection process I have undergone in this country. Before I received the result of my latest attempt, I was advised by another professor to go to the United States as I do not fit in the Brazilian system.

It seems that Brazil can produce good scientists for export, but this material does not bring income into the country.

Ricardo de Souza Pereira

Departamento de Parasitologia, Instituto de Ciencias Biomedicas, Universidade de São Paulo, Avenida Lineu Prestes 1374, Cidade Universitaria, São Paulo, Brazil

1. Nature 406, 826 (2000).

2. Walker, G. Yeast Physiology and Biotechnology 16-17 (Wiley, Chichester, 1998).

\section{If free speech costs lives that's a high price to pay}

Sir - Stewart et al. are right to remind us that the 17 years following the discovery of HIV have been a long time (Nature 407, 286; 2000).

Both of us lost grandparents and greatgrandparents to tuberculosis. One might have thought that in the hundred or more years since Robert Koch discovered Mycobacterium tuberculosis (without fulfilling all his postulates), we would have done a little better than the state we are in today: some 1.7 billion infected, with an annual death rate of 1.8 million. Of course we could all agree on tuberculosis being caused by another, as yet undiscovered, microbe riding on the intimate coat-tails of M. tuberculosis. Then perhaps the lack of progress would make sense. Paradigm lost.

In an earlier life one of us was valet to the French philosopher Voltaire. I remember cleaning his room one day, coming across a letter to Jean-Jacques Rousseau. As a Huguenot, I rejoiced at the remark, "I disapprove of what you say, but I will defend to the death your right to say it". What is not widely known is the next sentence: "My only question, Sir, is whether the columns of Nature are appropriate?".

We are staunch believers in the right to free speech, but is Nature the appropriate place to militate in favour of the preCopernican model of the universe or the existence of phlogiston? After all, there is Speakers' Corner in Hyde Park, when it's not raining. To demand the right of reply or equal time on such matters is a trick the creationists have used.

HIV causes AIDS. Problems arise when the proposed alternative costs lives. Simon Wain-Hobson ${ }^{\star}$, Robin A. Weiss $\uparrow$ ${ }^{*}$ Unité de Rétrovirologie Moléculaire, Institut Pasteur, 28 rue du Dr Roux, 75724 Paris cedex 15, France

$\dagger$ Windeyer Institute of Medical Sciences, University College London, 46 Cleveland Street, London W1T 4JF, UK 